\author{
옻나무 사료의 급여수준과 기간이 비육돈의 냉장중 육질에 \\ 미치는 영향 \\ 강선문* · 김동욱** . 이성기* \\ 강원대학교 동물식품응용과학과*, (주)농축산물공급센타**
}

\title{
Effect of Feeding Levels and Periods of Dietary Rhus verniciflua Stokes at Finishing Stage on the Meat Quality of Pigs during Refrigerated Storage
}

\author{
S. M. Kang*, D. W. Kim** and S. K. Lee* \\ Department of Animal Products and Food Science, Kangwon National University*, \\ Korea Restaurant Supply Center**
}

\begin{abstract}
This study was carried out to investigate the effect of feeding levels and periods of Rhus verniciflua Stokes (RVS) on the quality of $M$. longissimus from gilts (Landrace $\times$ Yorkshire $\times$ Duroc) at finishing stage. The gilts were fed diets containing 0 (control), 2 and 4\% RVS for 5 weeks (the latter feeding periods) and 8 weeks (the first feeding periods + the latter feeding periods) before slaughtering, respectively. Samples were stored at $3 \pm 0.2^{\circ} \mathrm{C}$ for 8 days. Crude fat content was decreased by feeding diets of $4 \%$ RVS $(\mathrm{p}<0.05)$. Water-holding capacity (WHC) was higher in RVS treatments than in control during storage $(\mathrm{p}<0.05)$. $\mathrm{L}^{*}($ Lightness $)$ value was higher in 5 weeks-RVS treatment than in control during storage $(\mathrm{p}<0.05)$. $\mathrm{a}^{*}$ (Redness) and $\mathrm{b}^{*}$ (yellowness) were not affected by the levels and periods of RVS supplementation. Thiobarbituric acid reactive substances (TBARS) value was lower in RVS treatment than in control $(\mathrm{p}<0.05)$, and the 5 weeks with $4 \%$ RVS treatment showed the highest antioxidative activity. Fatty acid compositions of pork were changed by RVS feeding levels and periods. The meat supplemented with RVS showed high levels of unsaturated fatty acid (UFA) composition and monounsaturated fatty acid (MUFA)/saturated fatty acid (SFA) ratio compared with control. The dietary 8 weeks-RVS treatments had lower stearic acid(18:0) and higher polyunsaturated fatty acid (PUFA) contents than in other treatments. Melting point of backfat also decreased by increasing the level and period of RVS supplementation $(\mathrm{p}<0.05)$. Therefore, RVS fed pork decreased fat content and melting point, increased WHC and UFA composition, and delayed lipid oxidation during storage.
\end{abstract}

(Key words: Dietary Rhus verniciflua Stokes, Pork quality, WHC, Lipid oxidation, Fatty acid composition)

$\begin{array}{cl}\text { I . 서 론 } & \text { 나무의 수액을 옻칠이라 하여 도료 및 공업용 } \\ & \text { 으로 사용되었으며, 한방에서는 구충, 복통, 통 } \\ \text { 옻나무과(Anacardiaceae)에 속하는 옻나무는 동 } & \text { 경, 변비, 빈혈 등의 약용약재로 이용되어 왔다 } \\ \text { 북아시아에서 자라는 낙엽활엽 소교목으로 옻 } & \text { (Shin, 1986). 옻나무의 주요 성분은 urushiol } 55\end{array}$

Corresponding author : Sung Ki Lee, Department of Animal Products and Food Science, Kangwon National University, Chunchon 200-701, Korea

Tel : +82-33-250-8646, Fax : +82-33-251-7719, E-mail : skilee@kangwon.ac.kr 
- 70\%, 고무질 4 8\%, 질소함유물 2 3\%, 효 소와 수분 $10 \sim 40 \%, 1 \sim 2 \%$ flavonoid이다(Jung, 1998). Urushiol은 피부가 민감한 서양인에게는 poison ivy(Toxicodendron radicans)로서 심한 알 레르기를 일으키기 때문에 서양에서는 옻나무 를 도료나 약용자원 측면에서 연구하지 않고 피부염이나 면역학적인 측면에서 연구가 수행 되어 왔으며(Epstein, 1989), 항AIDS, 항산화, 면 역증강 활성이 있음이 알려져 있다(Miller 등, 1996). 하지만 옻나무의 목질부에는 urushiol이 함유되어 있지 않고, flavonoid가 주로 함유되어 있기 때문에 알레르기를 유발시키지 않으며, 강장, 강정, 암 예방에 효과가 있는 것으로 알 려져 있다(Park 등, 2004).

옻나무의 flavonoid 성분과 그 활성에 대해 여 러 가지 연구들이 보고되었는데, Lee 등(2002) 은 옻나무 에탄올 추출물은 항산화 활성을 가 지고 있으며, 이 활성 성분들은 flavonoid 유도 체인 fustin, quercetin, butein, sulfuretin이라고 보 고하였다. Kim 등(1999)은 옻나무 에탄올 추출 물에서 클로로포름으로 분리한 페놀계 분획물 이 강한 항산화 활성을 가지고 있으며, 주요 활성 성분들은 gallic acid, butin 및 butein이라 고 하였다. 이러한 옻나무의 유익한 생리활성 을 육제품에 적용한 몇 가지 연구들이 보고되 었는데, Liang 등(2005a)은 옻 급여 한우육의 모델시스템을 통해 저장중 지방산화가 억제되 었다고 하였다. 또한 Lee 등(2005)은 옻 급여 돈육으로 제조한 소시지가 무급여 돈육으로 제 조한 소시지보다 냉장저장중 붉은 육색을 오랫 동안 유지하였고, 지방 산화와 단백질 부패가 억제되었으며, 조직감이 단단하였다고 보고한 바 있다.

가축의 옻나무 급여시험에 대한 연구의 경우 한우에게 옻나무 사료를 $4 \%$ 첨가하여 도축전 4 개월간 급여하면 고기의 보수력과 불포화지방 산 함량이 증가하고 저장기간중 육색 및 지방산 화가 안정되었다고 보고되었으나 $(\mathrm{Kim}$ 등, 2006), 돼지에서는 아직 체계적인 연구가 미흡한 실정 이다. 따라서 본 연구는 옻나무 사료를 돼지에 게 급여하여 급여수준과 기간에 따라 생산된 최종 육질을 냉장저장기간 동안 미치는 영향을
구명하고자 실시하였다.

\section{ㅍ. 재료 및 방법}

\section{1. 시험동물 및 사료}

돼지에게 옻나무 사료의 급여수준과 기간별 로 나누어 사육을 실시하였다. 경기도 가평축 협에서 미경산돈 $($ Landrace $\times$ Yorkshire $\times$ Duroc $)$ 을 생시체중 $80 \pm 0.4 \mathrm{~kg}$ 에서 5주(비육후기), 생시체 중 $65 \pm 5 \mathrm{~kg}$ 에서 8주(비육전기 : 3주, 비육후기 : 5주)동안 옻나무 사료를 각각 $0 \%$ (대조구), $2 \%$ 및 $4 \%$ 로 급여하였으며, 각 처리구당 5 두씩 공 시하였다. 물과 사료는 자유급식 시켰으며, 본 시 험에 이용한 사료의 성분 및 화학적 조성(NRC, 1988)은 Table 1(비육전기) 및 2(비육후기)와 같 다.

옻나무 사료는 강원도 원주에서 8년 동안 재 배한 옻나무(Rhus verniciflua Stokes)를 절단하여 자연건조 시켰으며, 수목과 수피를 톱밥파쇄기 로 1차 분쇄한 다음 분말기로 2차 분쇄하였다. 옻나무의 일반성분 함량은 수분 $24.03 \%$, 조지 방 $0.23 \%$, 조단백질 $0.73 \%$, 조회분 $1.32 \%$ 였다.

\section{2. 원료육의 처리}

시험완료된 비육돈을 도축 후 지육상태로 $2^{\circ} \mathrm{C}$ 에서 24 시간 동안 예냉하고 $\mathrm{A}$ 육가공장의 $15^{\circ} \mathrm{C}$ 작업실에서 발골 즉시 등심(M. longissimus)을 실험실의 $4 \pm 0.3^{\circ} \mathrm{C}$ 저온실로 운송하였다. 이후 등심 주변에 붙어있는 지방과 결체조직을 제거 한 후 순수 등심만 정형하였다. 표면육색 측정 을 위한 시료는 $5 \times 5 \times 1 \mathrm{~cm}$ 로 절단하고 식품포 장용 선상저밀도 폴리에틸렌 랩 필름(oxygen transmission rate $35,273 \mathrm{cc} / \mathrm{m}^{2} \cdot 24 \mathrm{hr} \cdot \mathrm{atm}, 0.01$ $\mathrm{mm}$ thickness, 3M Co., Korea)에 포장하였으며, 그 외 품질분석을 위한 시료의 경우 $3 \mathrm{~cm}$ 두께 로 절단하고 식품포장용 저밀도 폴리에틸렌 지 퍼백(LDPE, Cleanwrap zipper bag, Cleanwrap Co., $\mathrm{LTD}$, Korea)에 넣어 $3 \pm 0.2^{\circ} \mathrm{C}$ 냉장실(CRF1021D, Samsung, Korea)에서 8일 동안 저장하면서 실 험하였다. 
Table 1. The formula and chemical composition of experimental diets fed for 3 weeks (the first feeding periods)

\begin{tabular}{|c|c|c|c|}
\hline \multirow{2}{*}{ Ingredient (\%) } & \multicolumn{3}{|c|}{$\begin{array}{c}\text { Dietary Rhus verniciflua } \\
\text { Stokes (\%) }\end{array}$} \\
\hline & $\begin{array}{c}0 \\
\text { (Control) }\end{array}$ & 2 & 4 \\
\hline \multicolumn{4}{|c|}{ Nutrient composition (\%) } \\
\hline Corn & 58.89 & 55.15 & 50.80 \\
\hline Ricebran & 5.00 & 5.00 & 5.00 \\
\hline Dehulled-SBM & 27.40 & 27.85 & 28.50 \\
\hline Animal fat & 2.20 & 3.50 & 5.20 \\
\hline Molasses & 3.50 & 3.50 & 3.50 \\
\hline L-lysine (78\%) & 0.12 & 0.11 & 0.10 \\
\hline DL-methionine (100\%) & 0.03 & 0.03 & 0.04 \\
\hline Choline-chloride (25\%) & 0.04 & 0.04 & 0.04 \\
\hline Bactacid & 0.10 & 0.10 & 0.10 \\
\hline DCP & 1.15 & 1.15 & 1.15 \\
\hline Limestone & 0.85 & 0.85 & 0.85 \\
\hline Salt & 0.30 & 0.30 & 0.30 \\
\hline Mineral premix ${ }^{1)}$ & 0.20 & 0.20 & 0.20 \\
\hline Vitamin premix $^{2)}$ & 0.12 & 0.12 & 0.12 \\
\hline Probiotic & 0.10 & 0.10 & 0.10 \\
\hline Lacquer powder & & 2.00 & 4.00 \\
\hline Total & 100.00 & 100.00 & 100.00 \\
\hline \multicolumn{4}{|c|}{ Chemical composition (\%) } \\
\hline ME (kcal/kg) & 3,300 & 3,300 & 3,300 \\
\hline $\mathrm{CP}$ & 18.64 & 18.64 & 18.61 \\
\hline $\mathrm{Ca}$ & 0.70 & 0.70 & 0.70 \\
\hline Av-P & 0.30 & 0.30 & 0.30 \\
\hline Lys & 1.10 & 1.10 & 1.10 \\
\hline TSAA & 0.65 & 0.65 & 0.65 \\
\hline \multicolumn{4}{|c|}{ 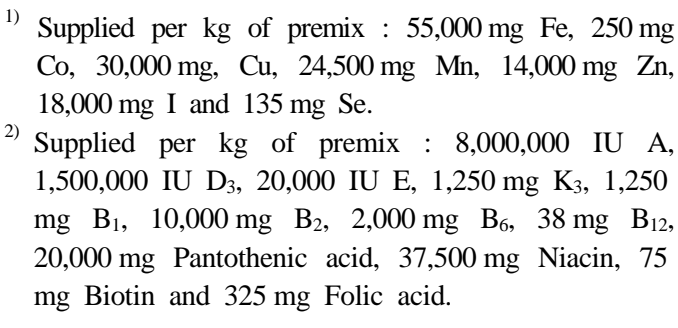 } \\
\hline
\end{tabular}

Table 2. The formula and chemical composition of experimental diets fed for 5 weeks (the latter feeding periods)

\begin{tabular}{|c|c|c|c|}
\hline \multirow{2}{*}{ Ingredient (\%) } & \multicolumn{3}{|c|}{$\begin{array}{c}\text { Dietary Rhus verniciflua } \\
\text { Stokes (\%) }\end{array}$} \\
\hline & $\begin{array}{c}0 \\
\text { (Control) }\end{array}$ & 2 & 4 \\
\hline & \multicolumn{3}{|c|}{ Nutrient composition (\%) } \\
\hline Corn & 66.24 & 62.46 & 58.27 \\
\hline Ricebran & 5.00 & 5.00 & 5.00 \\
\hline Dehulled-SBM & 20.20 & 20.90 & 21.60 \\
\hline Animal fat & 2.00 & 3.40 & 4.90 \\
\hline Molasses & 3.80 & 3.50 & 3.50 \\
\hline L-lysine (78\%) & 0.18 & 0.16 & 0.15 \\
\hline DL-methionine (100\%) & 0.02 & 0.02 & 0.03 \\
\hline Choline-chloride (25\%) & 0.04 & 0.04 & 0.04 \\
\hline Bactacid & 0.10 & 0.10 & 0.10 \\
\hline DCP & 0.90 & 0.90 & 0.91 \\
\hline Limestone & 0.80 & 0.80 & 0.78 \\
\hline Salt & 0.30 & 0.30 & 0.30 \\
\hline Mineral premix ${ }^{1)}$ & 0.20 & 0.20 & 0.20 \\
\hline Vitamin premix ${ }^{2)}$ & 0.12 & 0.12 & 0.12 \\
\hline Probiotic & 0.10 & 0.10 & 0.10 \\
\hline Lacquer powder & & 2.00 & 4.00 \\
\hline \multirow[t]{2}{*}{ Total } & 100.00 & 100.00 & 100.00 \\
\hline & \multicolumn{3}{|c|}{ Chemical composition (\%) } \\
\hline ME (kcal/kg) & 3,300 & 3,300 & 3,300 \\
\hline СР & 16.00 & 16.00 & 16.00 \\
\hline $\mathrm{Ca}$ & 0.60 & 0.60 & 0.60 \\
\hline Av-P & 0.25 & 0.25 & 0.25 \\
\hline Lys & 0.95 & 0.95 & 0.95 \\
\hline TSAA & 0.57 & 0.57 & 0.57 \\
\hline
\end{tabular}

1) Supplied per $\mathrm{kg}$ of premix : 55,000 mg Fe, $125 \mathrm{mg}$ $\mathrm{Co}, 4,500 \mathrm{mg}, \mathrm{Cu}, 7,000 \mathrm{mg} \mathrm{Mn}, 10,000 \mathrm{mg} \mathrm{Zn}$, $15,000 \mathrm{mg}$ I and $135 \mathrm{mg}$ Se.

2) Supplied per $\mathrm{kg}$ of premix : 8,000,000 IU A, $1,500,000 \mathrm{IU} \mathrm{D}_{3}, 20,000 \mathrm{IU}$ E, 1,250 mg K $, 1,250$ $\mathrm{mg} \mathrm{B}_{1}, 10,000 \mathrm{mg} \mathrm{B}_{2}, 2,000 \mathrm{mg} \mathrm{B}_{6}, 38 \mathrm{mg} \mathrm{B}_{12}$, 20,000 mg Pantothenic acid, 37,500 mg Niacin, 75 mg Biotin and $325 \mathrm{mg}$ Folic acid. 
3. 실험방법

(1) 일반성분 함량 및 $\mathrm{pH}$

일반성분 함량은 $\mathrm{AOAC(1995)}$ 방법에 의해 실시하였다. $\mathrm{pH}$ 는 세절한 시료 $10 \mathrm{~g}$ 과 증류수 $100 \mathrm{ml}$ 를 균질기(Nissei AM-7, Nihonseiki Kaisha Ltd., Japan)로 $10,000 \mathrm{rpm}$ 에서 1 분간 균질한 다 음 $\mathrm{pH}$ meter(F-12, Horiba, Japan)로 측정하였다.

(2) 보수력

보수력은 Hofman 등(1982)의 filterpaper press 법에 따라 실시하였다. 두개의 Plexi-glass plate $(11.5 \times 5.0 \times 0.8 \mathrm{~cm}) \quad$ 사이에 filterpaper(No. 2, Whatman International Ltd, England)를 놓고 세 절한 시료 $0.3 \mathrm{~g}$ 을 올린 다음 양쪽 나사를 이용 하여 5 분 동안 균일한 힘으로 압착시켰다. 이 후 digitizing area-line meter(Super PLANIX a, Tamaya Technics Inc., Japan)를 이용하여 내부 의 시료면적과 외부의 수분면적을 측정하여 보 수력(\%)을 산출하였다.

보수력 $(\%)=($ 내부의 면적 $/$ 외부의 면적 $) \times 100$

\section{(3) 표면육색}

시료의 표면육색은 color difference meter(CR-300, Minolta Co, Japan)를 이용하여 CIE L*(lightness), $\mathrm{a}^{*}$ (redness), b*(yellowness)을 측정하였으며, 저 장 0 일의 시료는 절단면을 최소 40 분 이상 두어 blooming시켰다. 이때 calibrate plate( $2^{\circ}$ observer $)$ 의 illuminant $\mathrm{C}$ 는 $\mathrm{Y}=93.0, \mathrm{x}=0.3140, \mathrm{y}=0.3026$ 이 었다.

\section{(4) TBARS(2-Thiobarbituric acid reactive substances)}

TBARS는 Sinnhuber와 $\mathrm{Yu}(1977)$ 의 방법에 의 해 $532 \mathrm{~nm}$ 에서 반응시킨 시료 용액의 흡광도를 spectrophotometer(UV-mini-1240, Shimadzu, Japan) 로 측정한 다음 시료 $\mathrm{kg}$ 당 $\mathrm{mg}$ malonaldehyde으 로 산출하였다.

\section{(5) 가열육의 TPA(Texture profile analysis)} Honikel(1998)의 방법에 따라 저밀도 폴리에틸
렌 지퍼백(LDPE, Cleanwrap zipper bag, Cleanwrap Co., LTD, Korea)에 넣은 등심 덩어리를 $75^{\circ} \mathrm{C}$ water bath에서 1 시간 동안 가열하였다. 가열후 시료를 $4 \pm 0.3^{\circ} \mathrm{C}$ 저온실에서 30 분 동안 냉각시 킨 다음 $2 \times 2 \times 1.5 \mathrm{~cm}$ 로 절단하였다. Cylinder probe $(\mathrm{P} / 5$, 직경 $5 \mathrm{~mm})$ 를 장착한 texture analyser (TA-XT2i version 6.06, Stable Micro Systems Co., Ltd, UK)로 경도(hardness), 탄력성(springiness), 응집성(cohesiveness), 뭉침성(gumminess), 씹힘성 (chewiness), 복원력(resiliense)을 분석하였다. 분 석 조건은 $\mathrm{Kim}$ 등(2003)의 방법에 따라 load cell $25 \mathrm{~kg}$, pre test speed $5.0 \mathrm{~mm} / \mathrm{s}$, test speed $2.0 \mathrm{~mm} / \mathrm{s}$, post test speed $5.0 \mathrm{~mm} / \mathrm{s}$, distance 11.0 $\mathrm{mm}$, trigger type force $30 \mathrm{~g}$ 으로 설정하였다.

\section{(6) 고기의 지방산 조성}

지방산 조성은 Folch 등(1957)의 방법에 의해 추출한 지방을 Sukhija와 Palmquist(1988)의 방 법에 의해 fatty acid methyl ester화 시킨 다음 ACEM 6000 GC(Young Lin Instrument Co., Ltd, Korea)에 의해 10 반복씩 분석하였으며, standard (PUFA No. 2, Animal source, Supelco, Bellefonate, $\mathrm{PA}, \mathrm{USA}$ )의 retention time과 비교하여 정성하 였다. 이때 GC의 분석 조건은 Table 3 과 같다.

Table 3. Analysis method of the fatty acid composition using GC

\begin{tabular}{ll}
\hline Experimental conditions GC \\
\hline \hline Column & HP-FFAP column \\
& $(30 \mathrm{~m}$ length $\times 0.25 \mathrm{~mm}$ id \\
& $\times 0.25 \mu \mathrm{m}$ film thickness, \\
& $\mathrm{J} \& \mathrm{~W}$ Scientific, USA) \\
Injector & Split $10: 1,1 \mu \mathrm{l}, 260^{\circ} \mathrm{C}$ \\
Carrier gas & Nitrogen at $2 \mathrm{ml} / \mathrm{min}$ \\
Oven temperature & $180^{\circ} \mathrm{C}$ for $10 \mathrm{~min}$ \\
& $180-250^{\circ} \mathrm{C}$ at $0.5^{\circ} \mathrm{C} / \mathrm{min}$ \\
& $250^{\circ} \mathrm{C}$ for $5 \mathrm{~min}$ \\
Detector & $280^{\circ} \mathrm{C}$, FID \\
\hline
\end{tabular}

\section{(7) 등지방의 융점}

Folch 등(1957)의 방법에 따라 등지방으로부 터 지방을 추출한 다음 $\mathrm{AOCS}(1990)$ 에 의해 직 
경 $0.8-1.1 \times$ 길이 $100 \mathrm{~mm}$ capillary tube(9530-2, $\mathrm{PYREX} \mathrm{P}, \mathrm{USA})$ 에 지방을 흡입시킨 후 즉시 $-20^{\circ} \mathrm{C}$ 냉동실(CRF1021D, Samsung, Korea)에 넣 었다. Capillary tube를 온도계의 수은주 방향에 고정시키고 직경이 $1.5 \mathrm{~cm}$ 시험관에 넣은 다음 water bath의 온도를 조금씩 올리면서 지방이 투명해질 때의 온도를 융점으로 기록하였으며, 처리구당 15 반복씩 수행하였다.

\section{4. 통계분석}

실험결과는 SAS(1999) program의 GLM(General Linear Model) procedure에 따라 처리되었으며, 각 처리구간에 유의성 검증을 위해 분산분석을 실시한 후 Duncan's multiple range test로 유의성 차이를 검증하였다.

\section{III. 결과 및 고찰}

\section{1. 일반성분 함량}

옻나무 사료의 급여수준과 기간이 돈육의 일 반성분 함량에 미치는 영향은 Table 4 와 같다. 수분, 조단백질, 조회분 함량에서는 옻나무 사 료의 급여수준과 기간에 따른 유의적인 차이가 나타나지 않았으나, 조지방 함량에서는 대조구 에 비해 옻 급여육이 낮은 경향을 보였다. 특 히 옻나무 사료 $4 \%$ 급여육이 사육기간과 상관 없이 대조구에 비해 지방함량이 유의적으로 낮 게 나타났다 $(\mathrm{p}<0.05)$. 그리고 통계적인 차이는
없었지만, 급여기간이 긴 8 주 급여육이 5 주 급 여육보다 지방함량이 더 낮은 경향을 보였다. 이와 같이 돼지에게 옻나무 사료를 급여하면 근육내 지방함량이 감소하게 된다. 거세 한우 에서도 도축전 4 개월 동안 옻나무 사료를 0,2 , $4,6 \%$ 급여시 수분, 조단백질, 조회분 함량에서 는 급여수준에 따른 차이가 나타나지 않았으나 등지방 두께, 근내지방도 및 조지방 함량은 급 여수준이 증가함에 따라 감소되었다는 유사한 보고가 있다(Kim 등, 2006; Liang, 2004).

\section{2. $\mathrm{pH}$ 및 보수력 비교}

옻나무 사료의 급여수준과 기간이 돈육의 냉 장중 $\mathrm{pH}$ 와 보수력에 미치는 영향은 Table 5와 같다. 모든 옻 급여육의 $\mathrm{pH}$ 는 대조구에 비해 저장기간 동안 약간 낮은 경향을 보였다. 저장 0 일에 대조구의 $\mathrm{pH}$ 는 5.47 인데 비해 8 주간 $4 \%$ 옻나무 급여육은 $5.41 \%$ 로 유의적인 감소를 보 였다 $(\mathrm{p}<0.05)$. 이와 같이 옻나무 사료를 장기적 으로 다량 급여할 경우 근육의 $\mathrm{pH}$ 에 영향을 끼치는 것으로 생각된다. 냉장저장기간 동안 일부 옻 급여육을 제외한 대부분의 시험 돈육 의 $\mathrm{pH}$ 는 약간씩 감소하는 경향을 보였다. 다만 8주간 $4 \%$ 옻 급여육의 $\mathrm{pH}$ 는 저장 0 일의 5.41 에서 8일의 5.42로, 오히려 0.01 만큼 증가하였 다. 이와 같은 결과를 종합해 보면 옻나무 사 료의 급여가 돈육의 $\mathrm{pH}$ 에 직접적으로 영향을 끼치지 않았고 저장기간 동안에도 급여육간 큰 차이를 나타내지는 않았다. 그러나 일부 고농

Table 4. Effect of feeding level and period of dietary Rhus verniciflua Stokes on the proximate composition (\%) of pork

\begin{tabular}{|c|c|c|c|c|c|}
\hline \multirow{3}{*}{ Items } & \multicolumn{5}{|c|}{ Dietary Rhus verniciflua Stokes supplementation } \\
\hline & \multirow{2}{*}{$\begin{array}{c}0 \% \\
\text { (Control) }\end{array}$} & \multicolumn{2}{|c|}{5 weeks } & \multicolumn{2}{|c|}{8 weeks } \\
\hline & & $2 \%$ & $4 \%$ & $2 \%$ & $4 \%$ \\
\hline Moisture & $73.72 \pm 0.10$ & $73.79 \pm 0.25$ & $73.83 \pm 0.16$ & $73.69 \pm 0.12$ & $73.92 \pm 0.14$ \\
\hline Crude fat & $2.60 \pm 0.06^{\mathrm{a}}$ & $2.59 \pm 0.05^{\mathrm{a}}$ & $2.46 \pm 0.11^{\mathrm{b}}$ & $2.49 \pm 0.07^{\mathrm{ab}}$ & $2.41 \pm 0.02^{\mathrm{b}}$ \\
\hline Crude protein & $22.68 \pm 0.07$ & $22.60 \pm 0.19$ & $22.86 \pm 0.26$ & $22.92 \pm 0.19$ & $22.88 \pm 0.24$ \\
\hline Crude ash & $1.01 \pm 0.03$ & $1.02 \pm 0.03$ & $1.03 \pm 0.02$ & $1.03 \pm 0.02$ & $1.03 \pm 0.02$ \\
\hline
\end{tabular}

$\overline{\mathrm{a}, \mathrm{b}}$ Means \pm standard deviation in the same row with different superscripts are significantly $\operatorname{different}(\mathrm{p}<0.05)$. 
Table 5. Effect of feeding level and period of dietary Rhus verniciflua Stokes on the $\mathrm{pH}$ value and water-holding capacity $(\mathrm{WHC})$ of pork during refrigerated storage

\begin{tabular}{|c|c|c|c|c|c|c|}
\hline \multirow{3}{*}{ Items } & \multirow{3}{*}{$\begin{array}{c}\text { Storage } \\
\text { days }\end{array}$} & \multicolumn{5}{|c|}{ Dietary Rhus verniciflua Stokes supplementation } \\
\hline & & \multirow{2}{*}{$\begin{array}{c}0 \% \\
\text { (Control) }\end{array}$} & \multicolumn{2}{|c|}{5 weeks } & \multicolumn{2}{|c|}{8 weeks } \\
\hline & & & $2 \%$ & $4 \%$ & $2 \%$ & $4 \%$ \\
\hline \multirow{4}{*}{$\mathrm{pH}$} & 0 & $5.47 \pm 0.04^{\mathrm{a}}$ & $5.46 \pm 0.02^{\mathrm{ab}}$ & $5.45 \pm 0.01^{\mathrm{ab}}$ & $5.45 \pm 0.04^{\mathrm{ab}}$ & $5.41 \pm 0.04^{\mathrm{b}}$ \\
\hline & 3 & $5.45 \pm 0.03^{\mathrm{ab}}$ & $5.45 \pm 0.01^{\mathrm{ab}}$ & $5.46 \pm 0.01^{\mathrm{a}}$ & $5.43 \pm 0.03^{\mathrm{b}}$ & $5.40 \pm 0.04^{b}$ \\
\hline & 6 & $5.44 \pm 0.05$ & $5.42 \pm 0.08$ & $5.42 \pm 0.05$ & $5.42 \pm 0.03$ & $5.40 \pm 0.05$ \\
\hline & 8 & $5.45 \pm 0.08^{\mathrm{a}}$ & $5.41 \pm 0.07^{\mathrm{b}}$ & $5.41 \pm 0.05^{\mathrm{b}}$ & $5.43 \pm 0.03^{\mathrm{a}}$ & $5.42 \pm 0.05^{\mathrm{b}}$ \\
\hline \multirow{4}{*}{ WHC (\%) } & 0 & $30.88 \pm 0.46^{\mathrm{cB}}$ & $38.76 \pm 0.36^{\mathrm{aD}}$ & $39.25 \pm 0.99^{\mathrm{aD}}$ & $34.25 \pm 1.80^{\mathrm{bC}}$ & $36.29 \pm 1.31^{\mathrm{bB}}$ \\
\hline & 3 & $35.01 \pm 2.48^{\mathrm{bB}}$ & $40.36 \pm 0.47^{\mathrm{aC}}$ & $41.11 \pm 0.43^{\mathrm{aC}}$ & $40.05 \pm 4.20^{\mathrm{aBC}}$ & $37.90 \pm 4.68^{\mathrm{abB}}$ \\
\hline & 6 & $42.12 \pm 4.65^{\mathrm{bA}}$ & $44.90 \pm 0.34^{\mathrm{abB}}$ & $49.67 \pm 0.44^{\mathrm{aB}}$ & $43.80 \pm 5.06^{\mathrm{aB}}$ & $44.20 \pm 4.30^{\mathrm{abA}}$ \\
\hline & 8 & $44.61 \pm 2.72^{\mathrm{cA}}$ & $50.20 \pm 0.35^{\mathrm{abA}}$ & $53.69 \pm 0.34^{\mathrm{aA}}$ & $49.88 \pm 1.48^{\mathrm{bA}}$ & $47.91 \pm 2.77^{\mathrm{bA}}$ \\
\hline
\end{tabular}

a,b,c Means \pm standard deviation in the same row with different superscripts are significantly $\operatorname{different}(\mathrm{p}<0.05)$.

A,B,C,D Means \pm standard deviation in the same column with different superscripts are significantly different( $\mathrm{p}<0.05)$.

도 급여육(8주간 $4 \%)$ 에서 저장 8 일간 $\mathrm{pH}$ 의 변 화가 적었다는 사실은 그 만큼 이화학, 미생물 적 변화가 지연되었을 가능성을 제시하고 있 다. 거세 한우육의 경우에도 냉장저장기간 동 안 옻나무 급여수준에 따른 $\mathrm{pH}$ 의 차이가 없었 다고 $\mathrm{Kim}$ 등(2006)이 보고한 바 있다.

보수력은 저장 0 일에 옻나무 사료를 5 주 동 안 $2 \%$ 와 $4 \%$ 급여육이 $38.76 \%$ 와 $39.25 \%$ 로 가 장 높게 나타났으며 $(\mathrm{p}<0.05), 8$ 주 동안 급여육 이 $34.25 \%$ 와 $36.29 \%$ 로 대조구의 $30.88 \%$ 보다 유의적으로 높게 나타났다 $(\mathrm{p}<0.05)$. 저장 8 일에 서도 옻나무 사료를 5 주간 급여육이 가장 높은 보수력을 나타내었고, 옻나무 사료를 급여한 모든 돈육이 대조구에 비해 높은 보수력을 나 타내었다. 이와 같은 결과를 보아 옻나무 사료 를 돼지에 급여하면 보수력이 향상되어 다즙성 증진에 기여하리라 판단되었다. $\mathrm{Kim}$ 등(2006) 은 옻나무를 $2 \%$ 및 $4 \%$ 급여한 한우육의 보수 력이 냉장저장기간 동안 옻나무를 $0 \%$ 급여한 한우육보다 유의적으로 높았다고 하였으며, Liang 등(2005b)은 옻나무를 $4 \%$ 및 $6 \%$ 급여한 한우 육의 드립감량이 해동후 냉장 5 일째부터 옻나 무 $0 \%$ 및 $2 \%$ 급여한 한우육보다 유의적으로
낮았다고 하였는데, 본 실험결과도 이러한 보 고들과 유사하였다. 저장기간에 따른 보수력의 변화를 살펴보면, 모든 처리구들에서 저장기간 동안 유의적으로 증가하는 경향을 보였으며, 이는 쇠고기의 숙성중 보수력이 증가하였다는 Greory 등(1991)의 보고와 유사한 경향을 나타 내었다.

\section{3. 표면육색 및 지방산화의 비교}

옻나무 사료의 급여수준과 기간이 돈육의 냉 장중 표면육색과 지방산화에 미치는 영향은 Table 6과 같다. 표면육색중 명도(L* 값)는 저 장 $0,3,6$ 일 동안 옻나무 사료를 5 주 동안 급 여한 돈육이 대조구와 8주 옻 급여육보다 유의 적으로 높게 나타났다 $(\mathrm{p}<0.05)$. 저장 8 일에는 옻나무를 5주간 $4 \%$ 급여육만 명도(L* 값)가 높 았다. 저장기간에 따른 명도 변화는 옻나무 사 료를 8 주 동안 $2 \%$ 급여육에서만 제외하고 모 든 돈육에서 감소하는 경향을 보였다.

적색도( $\mathrm{a}^{*}$ 값)는 옻 급여육이 대조구에 비해 전체적으로 낮은 경향을 보였다. 저장 0 일에 대조구의 a*값은 7.41 인데 비해 옻 급여육의 $a^{*}$ 
Table 6. Effect of feeding level and period of dietary Rhus verniciflua Stokes on the CIE color and TBARS values of pork during refrigerated storage

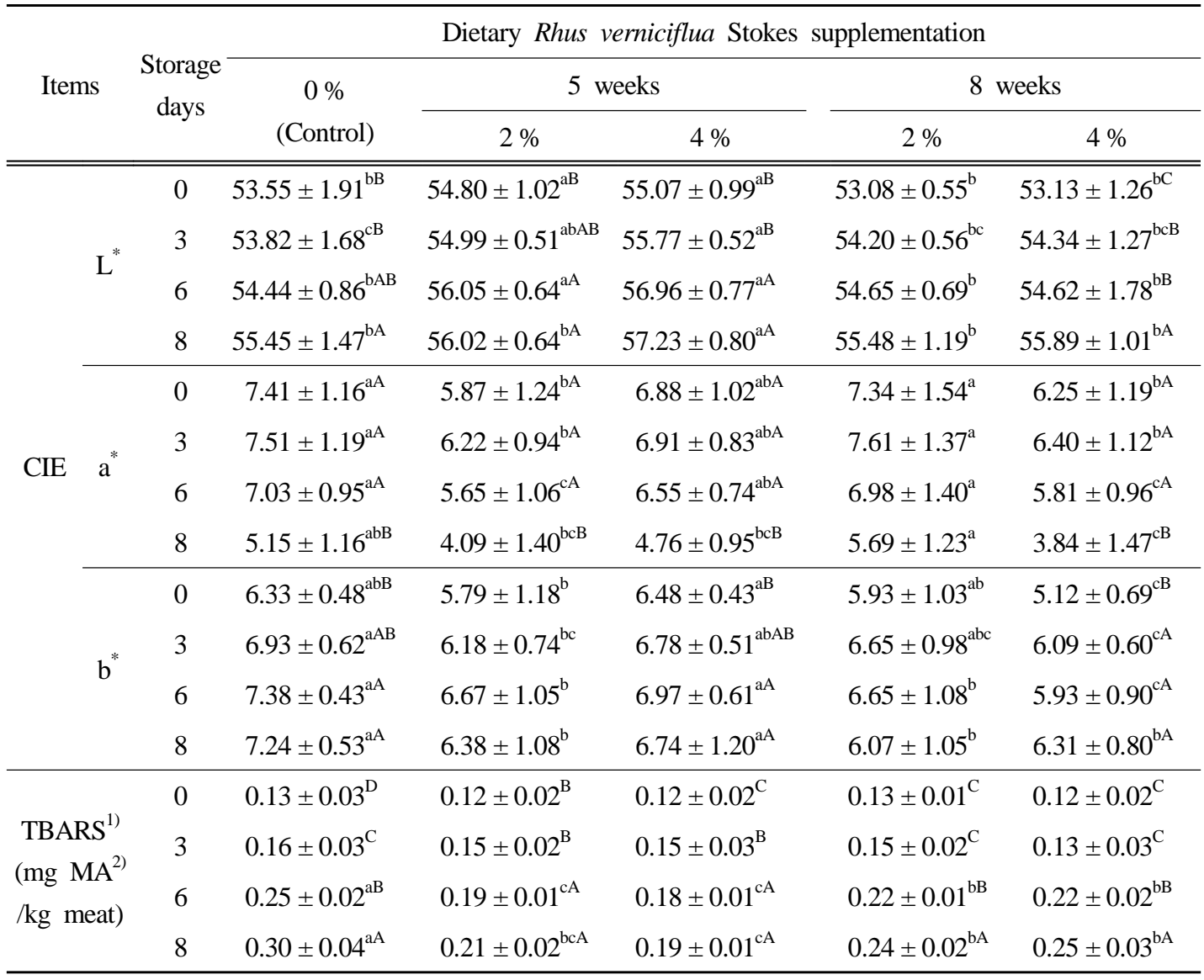

a,b,c Means \pm standard deviation in the same row with different superscripts are significantly different $(\mathrm{p}<0.05)$.

${ }^{\mathrm{A}, \mathrm{B}, \mathrm{C}}$ Means \pm standard deviation in the same column with different superscripts are significantly $\operatorname{different}(\mathrm{p}<0.05)$.

1) TBARS : 2-Thiobarbituric acid reactive substances. ${ }^{2)}$ MA : Malonaldehyde.

값은 5.87-7.34였다. 이와 같이 옻나무 사료를 돼지에게 급여하면 적색도가 대조구에 비해 79-99\%의 수준으로 감소함을 알 수 있었다. 옻 급여육중에서 8 주간 $2 \%$ 급여육은 저장 8 일간 대조구와 유의적인 차이를 보이지 않았지만, 8 주간 $4 \%$ 급여육은 저장 0 일의 6.25에 비해 8 일 에 3.84 로 $61 \%$ 수준만 유지하고 있어 적색 안 정성이 많이 떨어지는 것으로 나타났다.

옻나무 사료를 급여한 돈육의 황색도(b* 값) 는 전반적으로 대조구에 비해 낮은 경향을 보 였다. 대조구에 비해 8 주간 $4 \%$ 급여육에서 저 장 8 일간 유의적으로 낮게 나타났고, 8 주간 $2 \%$
급여육에서도 저장 6일과 8일에 대조구에 비해 유의적으로 낮았다. 다만, 옻나무 사료를 5주간 $4 \%$ 를 급여한 돈육만이 대조구와 유의적인 차 이가 없었다 $(\mathrm{p}>0.05)$. 저장기간동안 황색도는 비록 $2 \%$ 옻 급여육에서 유의적인 차이를 보이 지 않았지만, 모든 돈육이 저장기간중에 서서 히 증가하는 경향을 보였다.

이와 같은 결과를 종합해 보면, 옻나무 사료 의 급여육이 적색도와 황색도가 낮았기 때문에 색깔의 품질면에서 떨어진다고 할 수 있다. 반 추동물의 경우를 보면 도축전 4개월 동안 거세 한우에게 옻나무 $4 \%$ 를 급여하면 냉장저장기간 
동안 쇠고기의 육색이 가장 붉고 진하였다고 $\operatorname{Kim}$ 등(2006)이 보고한 바 있다. 고기에 따라 옻 급여 효과가 다른 이유는 반추동물인 소와 단위동물인 돼지간에 체내 대사상에서 차이가 있기 때문인 것으로 사료된다.

옻나무 사료의 급여수준과 기간에 따른 돈육 의 냉장중 지방산화를 TBARS로 나타내었다 (Table 6). 저장 3일까지 TBARS는 처리구간에 유의적인 차이가 없었으나 저장 6일 이후에는 옻 급여육이 대조구보다 유의적으로 낮게 나타 났다 $(\mathrm{p}<0.05)$. 저장 8 일에 있어서 산화정도를 보면 옻나무 사료를 5 주 동안 $4 \%$ 급여한 돈육 의 TBARS가 0.19로 옻나무 사료를 8주 동안 급여한 돈육의 $0.24,0.25$ 보다 유의적으로 낮게 나타났다 $(\mathrm{p}<0.05)$. 이러한 이유는 옻나무 성분 은 효소계의 catalase나 비효소계의 a-tocopherol 만큼 강한 항산화 활성을 가지고 있다고 하였 고(Lim and Shim, 1997), 활성 산소종을 제거하 고 산화된 물질을 환원시켜 산화에 의한 손상 으로부터 보호해 주기 때문이라고 하였다(Lee 등, 1999). 또한 옻나무 성분 중 quercetin은 금 속이온을 봉쇄하고 자유라디칼을 환원시켜주는 효과를 가지고 있다(Pratt and Watts, 1964).

이와 같이 옻나무 사료의 급여육은 대조구에 비해 냉장저장기간 동안 지방산화가 억제되었 으며, 특히 5 주간 급여육의 항산화 효과가 8 주
간 급여육보다 억제력이 높은 경향을 보였다. Kim 등(2006)과 Liang 등(2005b)은 옻나무를 급 여한 한우육의 TBARS가 냉장기간 동안 현저 히 억제되었다고 보고하였으며, 이는 본 실험 결과와 동일한 경향을 보였다. 따라서 가축에 게 옻나무를 급여함으로서 저장중 고기의 풍 미, 색깔, 조직감, 영양가, 안전성에 나쁜 영향 을 미치는 지방산화(Buckley 등, 1995)를 억제 시켜 육질을 향상시키는 것으로 판단된다.

\section{4. 가열육의 조직감 비교}

옻나무 사료의 급여수준과 기간이 돈육의 TPA (Texture profile analysis)에 미치는 영향은 Table 7 과 같다. 경도(hardness), 탄력성(springiness), 응집 성(cohesiveness), 뭉침성(gumminess), 씹힘성 (chewiness), 복원력(resiliense)은 대조구, 5주간 옻 급여육, 8 주간 $2 \%$ 급여육과 비교하였을 때 통계적 차이가 없었다. 다만 8 주간 $4 \%$ 의 옻 급 여육에서 경도, 뭉침성, 씹힘성이 대조구에 비 하여 유의적으로 높게 나타났다 $(\mathrm{p}<0.05)$. 본 실 험에서 가장 장기간 다량 급여구인 8주간 $4 \%$ 급여육에서 조직감이 가장 단단하게 나타났기 때문에 향후 옻나무 사료 섭취량의 증대가 조 직감에 미치는 효과에 대해 추가적인 연구가 필요하다고 판단된다.

Table 7. Effect of feeding level and period of dietary Rhus verniciflua Stokes on the texture profile analysis of pork during refrigerated storage

\begin{tabular}{|c|c|c|c|c|c|}
\hline \multirow{3}{*}{ Items } & \multicolumn{5}{|c|}{ Dietary Rhus verniciflua Stokes supplementation } \\
\hline & \multirow{2}{*}{$\begin{array}{c}0 \% \\
\text { (Control) }\end{array}$} & \multicolumn{2}{|c|}{5 weeks } & \multicolumn{2}{|c|}{8 weeks } \\
\hline & & $2 \%$ & $4 \%$ & $2 \%$ & $4 \%$ \\
\hline Hardness (g) & $2,956 \pm 514^{\mathrm{bc}}$ & $2,967 \pm 415^{\mathrm{bc}}$ & $2,714 \pm 305^{\mathrm{c}}$ & $3,372 \pm 667^{\mathrm{b}}$ & $3,349 \pm 446^{\mathrm{a}}$ \\
\hline Springiness & $0.84 \pm 0.07^{\mathrm{ab}}$ & $0.84 \pm 0.02^{\mathrm{ab}}$ & $0.85 \pm 0.07^{\mathrm{ab}}$ & $0.81 \pm 0.04^{\mathrm{b}}$ & $0.88 \pm 0.04^{\mathrm{a}}$ \\
\hline Cohesiveness & $0.42 \pm 0.02$ & $0.42 \pm 0.03$ & $0.43 \pm 0.03$ & $0.44 \pm 0.03$ & $0.45 \pm 0.03$ \\
\hline Gumminess & $1,238 \pm 241^{\mathrm{bc}}$ & $1,277 \pm 263^{\mathrm{bc}}$ & $1,153 \pm 130^{c}$ & $1,510 \pm 327^{\mathrm{ab}}$ & $1,789 \pm 189^{\mathrm{a}}$ \\
\hline Chewiness & $1,038 \pm 257^{\mathrm{b}}$ & $1,064 \pm 193^{b}$ & $971 \pm 66^{b}$ & $1,230 \pm 283^{b}$ & $1,549 \pm 167^{\mathrm{a}}$ \\
\hline Resiliense & $0.08 \pm 0.02^{\mathrm{b}}$ & $0.07 \pm 0.01^{\mathrm{b}}$ & $0.09 \pm 0.01^{\mathrm{ab}}$ & $0.10 \pm 0.01^{\mathrm{a}}$ & $0.09 \pm 0.01^{\mathrm{ab}}$ \\
\hline
\end{tabular}

$\overline{\mathrm{a}, \mathrm{b}, \mathrm{c}}$ Means \pm standard deviation in the same row with different superscripts are significantly $\operatorname{different}(\mathrm{p}<0.05)$. 
5. 고기의 지방산 조성 및 등지방의 융점 비교

Table 8은 시험 돈육의 지방산 조성을 나타 내고 있다. 옻나무 사료를 급여하면 돈육 지방 의 불포화지방산(UFA)이 증가하고 상대적으로 포화지방산(SFA)이 줄어드는 것으로 나타났다.

포화지방산인 palmitic acid(C16:0)는 5주와 8 주 옻 급여육의 각 $2 \%$ 에서 $21.17 \%$ 와 $21.31 \%$ 로 대조구의 23.33\% 보다 낮았고, steric acid(C18:0) 도 8 주 옻 급여육이 5주 옻 급여육과 대조구보 다 유의적으로 낮게 나타났다 $(\mathrm{p}<0.05)$. 반면, 단 가 불포화지방산(MUFA)인 oleic acid (C18:1)는 옻나무를 5 주와 8 주 동안 각각 $2 \%$ 급여육이 대 조구보다 유의적으로 높게 나타났다 $(\mathrm{p}<0.05)$. 옻 나무 사료를 8주간 4\%를 급여한 육에서 linoleic
acid(C18:2) 함량이 더 높았다.

이와 같이 단가 불포화지방산의 경우 옻나무 사료 급여량이나 기간에 상관없이 모두 대조구 에 비해 유의적으로 높았고 $(\mathrm{p}<0.05)$, 다가 불포 화지방산(PUFA)은 8주간 옻 사료를 급여한 돈 육에서 유의적으로 높게 나타났다 $(\mathrm{p}<0.05)$. 포화 지방산인 경우 대조구가 옻나무 사료를 5 주간 급여한 돈육보다 유의적으로 높았다 $(\mathrm{p}<0.05)$. 이 러한 결과는 옻나무를 한우육에서도 oleic acid (C18:1), UFA, MUFA, MUFA/SFA가 옻나무를 급여하지 않은 한우육보다 유의적으로 높았다 는 $\operatorname{Kim}$ 등(2006)의 보고와 유사하였다.

잘 알려졌다시피 식이로 인한 포화지방산의 증가는 인간의 혈장내 $\mathrm{LDL}$ 콜레스테롤과 총콜 레스테롤을 증가시키는 반면, 다가 불포화지방

Table 8. Effect of feeding level and period of dietary Rhus verniciflua Stokes on the fatty acid composition (\%) of pork and melting point of backfat

\begin{tabular}{|c|c|c|c|c|c|}
\hline \multirow{3}{*}{ Items } & \multicolumn{5}{|c|}{ Dietary Rhus verniciflua Stokes supplementation } \\
\hline & \multirow{2}{*}{$\begin{array}{c}0 \% \\
\text { (Control) }\end{array}$} & \multicolumn{2}{|c|}{5 weeks } & \multicolumn{2}{|c|}{8 weeks } \\
\hline & & $2 \%$ & $4 \%$ & $2 \%$ & $4 \%$ \\
\hline C14:0 (Myristate) & $1.58 \pm 0.28$ & $1.62 \pm 0.23$ & $1.35 \pm 0.19$ & $1.49 \pm 0.01$ & $1.48 \pm 0.15$ \\
\hline C16:0 (Palmitate) & $23.33 \pm 0.55^{\mathrm{a}}$ & $21.17 \pm 0.21^{\mathrm{b}}$ & $22.14 \pm 0.87^{\mathrm{ab}}$ & $21.31 \pm 0.35^{\mathrm{b}}$ & $22.37 \pm 1.33^{\mathrm{ab}}$ \\
\hline C16:1 (Palmitoleate) & $3.14 \pm 0.25$ & $3.21 \pm 0.34$ & $3.29 \pm 0.46$ & $3.73 \pm 0.54$ & $3.38 \pm 0.54$ \\
\hline C18:0 (Stearate) & $9.97 \pm 0.80^{\mathrm{a}}$ & $9.51 \pm 0.27^{\mathrm{a}}$ & $8.51 \pm 1.53^{\mathrm{b}}$ & $7.47 \pm 0.20^{\mathrm{c}}$ & $7.88 \pm 0.98^{\mathrm{bc}}$ \\
\hline C18:1 (Oleate) & $46.18 \pm 0.98^{\mathrm{b}}$ & $47.97 \pm 0.04^{\mathrm{a}}$ & $47.38 \pm 1.02^{\mathrm{ab}}$ & $47.91 \pm 1.27^{\mathrm{a}}$ & $47.67 \pm 0.75^{\mathrm{ab}}$ \\
\hline C18:2 (Linoleate) & $12.96 \pm 0.41^{b}$ & $12.98 \pm 0.67^{\mathrm{b}}$ & $13.13 \pm 1.28^{\mathrm{b}}$ & $13.41 \pm 1.05^{\mathrm{b}}$ & $14.79 \pm 1.32^{\mathrm{a}}$ \\
\hline C18:3 (Linolenate) & $0.46 \pm 0.12$ & $0.45 \pm 0.05$ & $0.45 \pm 0.36$ & $0.53 \pm 0.07$ & $0.47 \pm 0.37$ \\
\hline C20:1 (Eicosenoate) & $0.21 \pm 0.02$ & $0.26 \pm 0.02$ & $0.12 \pm 0.09$ & $0.20 \pm 0.24$ & $0.14 \pm 0.13$ \\
\hline C20:4 (Arachidonate) & $2.15 \pm 0.69$ & $2.81 \pm 0.05$ & $2.53 \pm 2.00$ & $2.81 \pm 0.05$ & $1.82 \pm 1.70$ \\
\hline Total & $100.00 \pm 0.00$ & $100.00 \pm 0.00$ & $100.00 \pm 0.00$ & $100.00 \pm 0.00$ & $100.00 \pm 0.00$ \\
\hline $\mathrm{SFA}^{1)}$ & $34.88 \pm 0.99^{\mathrm{a}}$ & $32.30 \pm 0.29^{\mathrm{b}}$ & $32.00 \pm 1.20^{\mathrm{b}}$ & $31.41 \pm 0.16^{\mathrm{ab}}$ & $31.73 \pm 2.41^{\mathrm{ab}}$ \\
\hline MUFA $^{2)}$ & $49.53 \pm 1.44^{\mathrm{b}}$ & $51.46 \pm 0.23^{\mathrm{a}}$ & $51.89 \pm 1.08^{\mathrm{a}}$ & $51.84 \pm 1.34^{\mathrm{a}}$ & $51.19 \pm 1.65^{\mathrm{a}}$ \\
\hline PUFA $^{3)}$ & $15.59 \pm 0.52^{b}$ & $16.24 \pm 0.52^{\mathrm{ab}}$ & $16.11 \pm 3.53^{\mathrm{ab}}$ & $16.75 \pm 1.90^{\mathrm{a}}$ & $17.08 \pm 3.52^{\mathrm{a}}$ \\
\hline MUFA/SFA & $1.42 \pm 0.05^{\mathrm{c}}$ & $1.59 \pm 0.01^{\mathrm{b}}$ & $1.62 \pm 0.02^{\mathrm{ab}}$ & $1.65 \pm 0.05^{\mathrm{a}}$ & $1.61 \pm 0.12^{\mathrm{ab}}$ \\
\hline Melting point $\left({ }^{\circ} \mathrm{C}\right)$ & $48.89 \pm 1.09^{a}$ & $47.68 \pm 0.92^{\mathrm{ab}}$ & $46.42 \pm 2.16^{\mathrm{b}}$ & $46.78 \pm 0.81^{b}$ & $44.68 \pm 1.28^{c}$ \\
\hline
\end{tabular}

$\overline{a, b, c}$ Means \pm standard deviation in the same row with different superscripts are significantly different $(\mathrm{p}<0.05)$.

1) Saturated fatty acid. ${ }^{2)}$ Monounsaturated fatty acid. ${ }^{3)}$ Polyunsaturated fatty acid. 
산을 감소시키며(Mensink and Katan, 1992; Yu 등, 1995), 다가 불포화지방산의 경우 혈장 콜 레스테롤을 감소시킴으로서 심혈관계 질병의 위험도를 감소시킨다(Van Oeckel 등, 1997). 따 라서 옻나무 사료를 돼지에게 급여시 고기내 다가 불포화지방산이 증가되어 인간의 건강에 유익하리라고 사료된다.

Table 8의 하단에서 보는바와 같이 옻나무 사료의 급여가 돈지방의 융점에 밀접한 영향 을 끼치는 것으로 나타났다. 옻나무 사료를 8 주간 $4 \%$ 를 급여한 육이 $44.68^{\circ} \mathrm{C}$ 로 모든 처리 구중에서 가장 낮았고, 이어 8 주간 $2 \%, 5$ 주간 $4 \%$ 급여육이 나머지 돈육 보다 유의적으로 낮 았다 $(\mathrm{p}<0.05)$. 이와 같이 옻나무 사료의 첨가량 이나 기간이 길수록 지방의 융점이 낮아지는 경향을 보였다.

지방의 융점은 지방산의 C18:0과 C18:2의 함 량에 의해 영향을 받으며, 특히 C18:0과 가장 높은 상관성을 가지고 있다(Wood 등, 1978). 또 한 지방내 불포화도가 증가할수록 융점이 낮아 진다(Davanel 등, 1999, Warnants 등, 1996). 따 라서 본 실험결과에서 옻나무 사료급여로 인해 돈육내 포화지방산인 stearic acid (C18:0)가 감 소하고, 단가 및 다가 불포화지방산이 증가하 였기 때문에 지방의 융점이 대조구보다 낮았을 것으로 사료된다.

\section{IV. 요 약}

비육돈에게 옻나무 사료의 첨가수준과 급여기 간이 도축 후 육질에 미치는 영향을 구명하기 위해 본 실험을 실시하였다. 생시체중이 $80 \mathrm{~kg}$ 과 $65 \mathrm{~kg}$ 인 미경산돈(Landrace $\times$ Yorkshire $\times$ Duroc $)$ 을 도축전 5주(비육후기)와 8주(비육전기 : 3주; 비 육후기 : 5주)동안 옻나무 사료를 $0 \%$ (대조구), $2 \%$ 및 $4 \%$ 로 처리구당 5 두씩 급여하였다. 도축 후 24시간동안 냉각시킨 다음 발골한 등심 $(M$. longissimus)을 $3 \pm 0.2^{\circ} \mathrm{C}$ 에서 8 일 동안 저장하면 서 실험을 실시하였다. 일반성분 함량에서 옻 나무 사료를 $4 \%$ 급여한 돈육이 대조구에 비해 조지방 함량이 감소하였다 $(\mathrm{p}<0.05)$. 보수력은 옻 급여육이 대조구보다 높았다 $(\mathrm{p}<0.05)$. 표면육색
에서 명도( $\mathrm{L}^{*}$ 값 $)$ 는 저장기간 동안 옻나무 사 료를 5주간 급여육이 대조구보다 높았으나 $(\mathrm{p}<0.05)$, 적색도 $\left(\mathrm{a}^{*}\right.$ 값 $)$ 와 황색도( $\mathrm{b}^{*}$ 값 $)$ 는 옻나 무 급여수준과 기간에 따른 영향을 받지 않았 다. TBARS는 저장기간중에 옻나무 급여육이 대조구보다 낮았으며 $(\mathrm{p}<0.05)$, 옻나무 사료를 5 주간 급여육이 가장 높은 항산화 효과를 보였 다. 옻나무 사료를 급여하면 돈육 지방의 불포 화지방산이 증가하고 상대적으로 포화지방산이 줄어드는 것으로 나타났다. 단가 불포화지방산 (MUFA)의 경우 옻나무 사료 급여량이나 기간 에 상관없이 모든 옻 급여육이 대조구에 비해 유의적으로 높았고, 다가 불포화지방산(PUFA) 은 8주간 옻나무 사료를 급여한 돈육에서 유 의적으로 높게 나타났다 $(\mathrm{p}<0.05)$. 반면 포화지 방산의 경우 옻나무 사료를 5주간 급여한 돈 육이 대조구보다 유의적으로 낮았다 $(\mathrm{p}<0.05)$. 등지방의 융점은 옻나무 사료의 급여수준과 기간이 증가함에 따라 감소하였다 $(\mathrm{p}<0.05)$. 따 라서 옻나무 사료를 비육돈에게 급여하면 돈 육의 지방 함량이 줄어드나 보수력 및 불포화 지방산이 증가되며, 냉장기간중 지방산화가 억 제되었다.

$$
\mathrm{V} \text {. 사 사 }
$$

본 연구는 2003년도 가평 축협지원(24030021-1)으로 수행된 연구결과의 일부이며, 이에 감 사를 드립니다.

\section{VI. 인 용 문 헌}

1. AOAC. 1995. Official Methods of Analysis, 16th ed. Association of Official Analytical Chemists, Washington, D.C., U.S.A.

2. AOCS. 1990. Official and Tentative Methods of the American Oil Chemists' Society, 15th ed. AOCS Press, Champaign, U.S.A.

3. Buckley, D. J., Morrissey, P. A. and Gray, J. I. 1995. Influence of dietary vitamin $\mathrm{E}$ on the oxidative stability and quality of pig meat. J. Anim. Sci. 73:3122-3130. 
4. Davanel, A., Riaublanc, A., Marchal, P. and Gandemer, G. 1999. Quality of pig adipose tissue: Relationship between solid fat content and lipid composition. Meat Sci. 51:73-79.

5. Epstein, W. L. 1989. Topical prevention of poison ivy/oak dermatis. Arch. Dermatol. 125:499-501.

6. Folch, J., Lees, M. and Stanley, G. A. S. 1957. A simple method for the isolation and purification of total lipids form animal tissues. J. Biol. Chem. 226:497-509.

7. Gregory, E. M., Janet, E. G., Sheryle, A. R., Lian, T. T., Ross, J. N. and Drew, M. F. 1991. Tenderizing, ageing, and thawing effects on sensory, chemical, and physical properties of beef steaks. J. Food Sci. 56:1125-1129.

8. Hofman, K., Hamm, R. and Blüchel, E. 1982. Neunes Über die Bestimmung der Wasserbindung des Fleisches mit Hilfe der Filterpapierpressmethode. Fleischwirt. 62:87-92.

9. Honikel, K. O. 1998. Reference methods for the assessment of physical characteristics of meat. Meat Sci. 49:447-457.

10. Jung, N. C. 1998. Biological activity of urushiol and flavonoids from lac tree (Rhus verniciflua Stokes). Ph. D. thesis, Chonnam National Univ., Kwangju, Korea.

11. Kim, D. W., Liang, C. Y., Kim, Y. S., Kang, C G and Lee, S. K. 2003. Effects of addition of extracted Rhus verniciflua Stokes and supplementation on the meat quality of pork. Annals of Animal Resources Science 14:34-41.

12. Kim, L. W., Shin, D. H. and Baek, N. L. 1999. Identification of antioxidative components from ethanol extract of Rhus verniciflua Stoke. Korean J. Food Sci. Technol. 31:1654-1660.

13. Kim, Y. S., Liang, C. Y., Song Y. H. and Lee, S. K. 2006. Effects of dietary Rhus verniciflua Stokes supplementation on meat quality characteristics of Hanwoo (Korean cattle) beef during refrigerated storage. Asian-Aust. J. Anim. Sci. 19:113-118.

14. Lee, J. C., Jung, H. Y. and Lim, K. T. 1999. Effects of Rhus verniciflua Stokes (RVS) on the plasma level of cholesterol and tumor growth in mouse. J. Toxicol. Public Health 15: 169-175.

15. Lee, J. C., Lim, K. T. and Jang, Y. S. 2002. Identification of Rhus verniciflua Stokes compounds that exhibit free radical scavenging and anti-apototic properties. Biochimica et Biophysica Acta 1570:181-191.

16. Lee, S. K., Kang, S. M., Kim, Y. S. and Kang, C. G. 2005. Quality comparison of emulsion-type sausage made from Rhus verniciflua Stokes fed pork and extract. Korean J. Food Sci. Ani. Resour. 25:210-217.

17. Liang, C. Y. 2004. Effect of dietary Rhus verniciflua Stokes supplementation on the quality of Hanwoo (Korean cattle) beef. Ph. D. thesis. Kangwon National Univ., Chunchon, Korea.

18. Liang, C. Y., Kang, S. M., Kim, Y. S. and Lee, S. K. 2005a. Antioxidant activity of Rhus verniciflua Stokes extract in model systems and cooked beef. Korean J. Food Sci. Ani. Resour. 25:189-195.

19. Liang, C. Y., Kang, S. M., Kim, Y. S. and Lee, S. K. 2005b. Effect of dietary Rhus verniciflua Stokes on the quality of Hanwoo (Korean cattle) beef during cold storage after thawing. Korean J. Food Sci. Ani. Resour. 25:196-202.

20. Lim, K. T. and Shim, J. H. 1997. Antioxidant effects of ethanol extracts from Rhus verniciflua Stokes (RVS) on mouse whole brain cells. Korean J. Food Sci. Technol. 29:1248-1254.

21. Mensink, R. P. and Katan, M. B. 1992. Effect of dietary fatty acids on serum lipids and lipoproteins. A metaanalysis of 27 trials. Arterioclerosis and Thrombosis 12:911-919.

22. Miller, W. C., Thielman, N. M., Swai, N., Cegieski, J. P., Shao, J., Ting, D., Mlalasi, J., Manyenga, D. and Lallinger, G. J. 1996. Delayedtype hypersensitivity testing in Tanzanian adults with HIV infection. J. Acquir. Immune Defic. Syndr. 12:303-308.

23. NRC. 1988. Nutrient Requirements of Swine. 9th ed. National Academy Press, Washington, D.C., 
U.S.A.

24. Park, K., Jung, G., Lee, K., Choi, J., Choi, M., Kim, G., Jung, H. and Park, H. 2004. Antimutagenic activity of flavonoids from the heartwood of Rhus verniciflua. J. Ethnopharmacol. 90:73-79.

25. Pratt, D. E. and Watts, B. M. 1964. The antioxidant activity of vegetable extract I : Flavone aglycones. J. Food Sci. 29:27-33.

26. SAS. 1999. SAS/STAT software for PC. Release 8.01. SAS Institute Inc., Cary, N.C., U.S.A.

27. Shin, M. K. 1986. Coloured Limsangbonchohak. Namsandang, Seoul, Korea, p. 165-718.

28. Sinnhuber, R. O. and Yu, T. C. 1977. The 2-thiobarbituric acid reaction, an objective measure of the oxidative deterioration occurring in fats and oils. J. Jap. Soc. Fish. Sci. 26:259-267.

29. Sukhija, P. S. and Palmquist, D. L. 1988. Rapid method for determination of total fatty acid content and composition of feedstuffs and feces.

J. Agric. Food Chem. 36:1202-1206.
30. Van Oeckel, M. J., Casteels, M., Warnants, N. and Boucqué, C. H. V. 1997. Omega-3 fatty acids in pig nutrition : Implications for zootechnical performances, carcass and fat quality. Archives of Animal Nutrition 50:31-42.

31. Warnants, N., Van Oeckel, M. J. and Boucqué, Ch. V. 1996. Incorporation of dietary polyunsaturated fatty acids in pork tissues and its implications for quality of end products. Meat Sci. 44:125-144.

32. Wood, J. D., Enser, M., MacFie, H. J. H., Smith, W. C., Chadwick, J. P. and Ellis, M. 1978. Fatty acid composition of backfat in Large White pigs selected for low backfat thickness. Meat Sci. 2:289-300.

33. Yu, S., Derr, J., Etherton, T. D., Johnson, J. A. and Dallal, G. E. 1995. Plasma cholesterolpredictive equations demonstrate that stearic acid is neutral and monounsaturated fatty acids are hypocholesterolemic. The American Journal of Clinical Nutrition 61:1129-1139.

(접수일자 : 2006. 7. 18. / 채택일자 : 2006. 9. 11.) 